\title{
A Study on English Collocation Errors of Thai EFL Students
}

\author{
Thidakul Boonraksa ${ }^{1} \&$ Suparvadee Naisena ${ }^{1}$ \\ ${ }^{1}$ Division of Foreign Languages, Nakhonsawan Rajabhat University, Nakhonsawan, Thailand \\ Correspondence: Thidakul Boonraksa, Division of Foreign Languages, Nakhonsawan Rajabhat University, \\ Nakhonsawan, Thailand.
}

Received: November 24, 2021

Accepted: December 28, 2021

Online Published: December 29, 2021

doi: $10.5539 /$ elt.v15n1p164

URL: https://doi.org/10.5539/elt.v15n1p164

\begin{abstract}
Collocation is an often-neglected language form that foreign language teachers and students should focus on to achieve competence in a target language. In this research, the researchers studied purposely to facilitate both second language teachers and students to produce correct and appropriate collocations. The purposes of this research were 1) to study the collocation error levels of Bachelor of Arts English and Business English students studying at Northern Rajabhat University, 2) to study the relationship between first language (L1) and second language (L2) transfer collocation errors in students' writing, and 3) to compare the collocation errors between high-proficiency students, medium- proficiency students and low-proficiency students. The research sample included 285 Thai EFL students enrolled in second-year English and Business English programs at Northern Rajabhat University during the first semester of the academic year 2021. The research instrument was a collocation proficiency test with 54 questions, which was divided into 2 sections: 1) 36 questions with 4 multiple-choice tests, and 2) 18 Thai to English translation questions. The items were chosen from the Oxford $3000^{\mathrm{TM}}$, and were common vocabulary appearing in various contexts. Research data were analyzed using mean, standard deviation, t-test (Dependent), and Friedman test.

The research found that 1) the level of Grammatical Collocation errors of high-proficiency EFL students was at a moderate level, medium-proficiency and low-proficiency EFL students were at a high level, and for Lexical Collocation errors, all three groups of students were at a high level; 2) the EFL students' collocation errors were caused by the language transfer from their first language (L1) to their second language (L2), synonyms, and lack of collocation competency; and 3) the most Lexical Collocation errors found in all student groups were Adverb + Adjective. For Grammatical Collocation, all groups could use Verb + Preposition better than Noun + Preposition, and the high proficiency and medium proficiency students could perform Adjective + Preposition the least, whilst the low proficiency students were better at Adjective + Preposition.
\end{abstract}

Keywords: collocation, errors, EFL students, grammatical collocation, lexical collocation

\section{Introduction}

Vocabulary has a significant role in English learning, whether as a second language or as a foreign language, and is an important part of language learning because it allows people to communicate more effectively (Vygotsky, 1986). During second language learning, students need to comprehend the vocabulary in that language. Students who obtain a large amount of vocabulary as well as knowledge of the different types of vocabulary tend to have better language acquisition levels and communication ability.

Many linguists such as Lewis (2001), Nation (2001), Shamsudin et al. (2013), Nasrin S. (2016), Sanguannam (2017) Li-Wei et al. (2021) and Bui, T. L. (2021) all agree that collocation is significant for EFL / ESL students to use language accurately and fluently, or that collocation is the key to language fluency. Firth (1968) was the first linguist to define collocation as the common co-occurrence of particular words. Halliday and Hasan (1976) also stated that "collocation is the co-occurrence of two words, independent of grammatical types and likely to take place over sentence boundaries". In addition, Nation (2001) Benson et al. (2009), McIntosh (2009), McCarthy and O'Dell (2005), and Tanihardjo (2017) described collocation as a group of co-occurrences of two or more words that are always used together normally, both in spoken and written languages; such as take a chance, make a mistake or a difficult decision. Ashiba (2017) and Qader (2018) also mentioned that collocation is the combination of two or more words to create new meaning. 
In conclusion, collocation is the co-occurrence of two or more words to form new combinations of words with different meanings according to situational context. For example, "break down" and "break a leg" both have the word "break" in them but each has a different meaning; break down means damaged / fractured, while break a leg means good luck.

Collocation has been described as one of the most difficult aspects of English usage by English language specialists, such as Harold E. Palmer (1949), who stated that most errors in the writing of English essays by international students are related to vocabulary. There are approximately 1,000 regularly used English vocabulary words that do not cause any trouble for native English speakers. On the other hand, this core vocabulary is the reason international students cannot perform in English properly or effectively. Wattanapichet (1999) also mentioned that although students are taught both English grammar and vocabulary, they still cannot speak or write English as fluently as native users due to various language structures not following general grammatical rules and needing to be learned separately.

When it comes to English teaching and learning in Thailand, most students have been taught only vocabulary and grammar. Most of the English vocabulary are used as a set of words or phrases, including key elements to construct standard English sentences, which are Vocabulary + Grammar + Collocation. The collocations are the linking words, word placements, or phrases that must be applied in standard sentences that are commonly used by native speakers. This is the main reason most people from Thailand cannot write and speak in standardized English (Intaraprasit, 2013). In Thailand, most English teaching focuses on grammar and vocabulary, and neglects collocations. Other researchers such as Boonyasaquan (2006), Jindapitak (2014), Savika Varaporn (2013) and Iamsirirak (2017), all agreed that in foreign language lessons, grammatical structures and meanings of new terms were valued more highly than collocations. Many English teachers, particularly in Thailand, are focused on grammar-based instruction for students, which includes both grammar and translation. For Thai students, English grammar courses were delivered in the form of a worksheet or a list of rules with examples, which they were expected to memorize and/or duplicate. For decades, grammar has been an important aspect of studying English in Thailand. Thai students, on the other hand, are unable to communicate effectively in English. Hill (2000) as cited in Kuo (2009, p. 141) mentions that teachers mostly focus on fixing grammatical errors without fixing any collocation mistakes. It can be said that most teachers and instructors consider learning the English grammar system essential to making communication more effective. As a result, Thai students are unable to use English properly and naturally, and as mentioned by Puimom, Kerdthong, and Nimsa-Ard (2012), students are regularly taught to focus firstly on grammar whilst neglecting communication skills and vocabularies such as verb phrases, idioms, slang, and collocations. Lacking collocation competence, the recipient, especially native speakers, may not understand or be confused by the meaning the speakers or writers try to convey (McCarthy \& O’Dell, 2007). Wilkins (1972 as cited in Lewis (Ed.), 2000) also stated that communication can occur without grammar, while it is impossible to communicate without vocabulary. As such, in language learning, teachers should add collocation content to various subjects. It can be concluded that collocation is a major element in the English language but is severely neglected in English studies. Moreover, focusing on memorizing large amounts of vocabulary cannot lead to English learning achievement when compared to understanding collocations, and students can use English more effectively if they understand collocation.

Besides a lack of knowledge and understanding of collocation that prevents EFL learners from using English accurately and properly, several studies have suggested that language transferring is another major cause. It influences EFL learners' language learning and results in EFL learners making Collocation errors. Various experts have defined the concept of language transfer, such as Odlin (1989), who stated that language transfer is the influence on a language used, and the similarity or difference between a target language and a mother tongue. Ellis (1994) said that language transfer determines the difficulty of the target language or the students' second language, and if that language has the same structure as the mother tongue, the learning process will be easier. Alternatively, more differences between the target language and mother tongue means it will be more difficult to learn and easier for mistakes to occur. Most mistakes with EFL students are found in collocations due to mother tongue interference (Phoocharoensil, 2014). Collocations cause problems for EFL students because they have a characteristic that cannot be clarified with reasons or grammatical rules (Thanalertkul, 2009). Brown (2000) also said that language transfer and overgeneralization are basic strategies that ESL and EFL students utilize whilst learning a language, and overgeneralization commonly occurs when combining two unfamiliar words or structures. Moreover, Yamashita and Jiang (2010) pointed out that a students' native language or mother tongue influences their usage of collocations. The mother tongue interferes while transferring the native language to the second language as the old knowledge merges with the new. This is a concept shared among many linguists at 
the International TEFL and TESOL Training (2019) who mentioned that students' learning systems will constantly be interfered with by their native language due to their familiarity with the language, causing mother tongue interference. As such, the influence of the mother tongue on second language learning can be divided into 2 parts. Positive transfer, which is the transferring of the characteristics or structures of the mother tongue that have some similarity with the target or second language, causing students to improve their second language faster and more accurately. On the other hand, negative transfer involves transferring characteristics or structures from the mother tongue that are inconsistent or improper for the second language, which can result in language errors (Richards, Platt, \& Platt, 1993). Research by Cao and Badger (2021) on "Cross-linguistic influence on the use of L2 collocations" discovered that first languages (L1) influenced $40 \%$ of collocations, and that errors linked with inappropriate preposition use in verb-noun collocations (e.g. preposition addition, omission, or misuse) are significantly L1-motivated. Students made mistakes with both incongruent and congruent collocations (collocations that have no direct L1 equivalents and with direct L1 translations).

The study of these errors is the subject of a significant amount of domestic and international collocation research such as Hatice ZATA's study on Turkish EFL Learners' Use of English Collocations (2020), Sridhanyarat Kietnawin (2018) studied about Acquisition of L2 Collocations by Thai Learners: An Interlanguage Perspective, McLellan and Chorbwhan (2016) Thai Learners' First Language Transfer and English Collocation Acquisition, Yumanee and Phoocharoensil's research on the Analysis of Collocational Errors in Thai EFL Students (2013) and Phoocharoensil studied the Cross-linguistic Influence: Its Impact on L2 English Collocation Production. For example, Boonyasaquan (2005) studied collocational violations in translation, investigating the translation of a business news article from Thai to English by 32 BA English language major students at Srinakharinwirot University in Thailand. Verb + Noun, Adjective + Noun, Noun + Noun, Adverb + Verb, Adverb + Adjective, Noun + Verb, and Verb + Preposition were the eight collocation patterns studied. The findings revealed that the informants' ability to effectively translate a business document from Thai to English using collocations was low. Moreover, Detdamrongpreecha (2014) mentioned that direct translation from L1 to L2 borrowing of mother-tongue, inadequate knowledge of culture and vocabulary, and use of de-lexicalized words were all variables impacting learners' English receptive and productive collocation ability. As well as Bennui (2008) who found that instead of writing "The price is low", Thai students commonly write "The price is cheap". This is since in verbal and written communication, Thai people prefer the word "cheap" rather than "low". Another aspect found in the research is that in terms of L1 lexical interference, they utilize Thai words incorrectly in their written English. Due to the students' straight translation of the Thai word into English, the word "water cat" or /mewnam/ was used instead of seal.

The informants had difficulty with both lexical and grammatical collocations. Wongpunya and Meesri (2019) investigated low proficiency level Thai EFL students' misuse of collocations by collecting data from two types of collocation tests: Lexical Collocation (Verb + Noun / Adjective + Noun) and Grammatical Collocations (Noun + Preposition / Adjective + Preposition). The study found that an overview of the sample contained more errors in Lexical Collocation than Grammatical Collocations, with the most errors in the use of adjectival collocations (Adjective + Noun). Examples are as follows:

The collocation

$$
\begin{array}{ll}
* \text { powerful coffee } & \text { instead of } \\
* \text { relax room } & \text { instead of }
\end{array}
$$

strong coffee

The collocation

relaxing room

The collocation

*huge mistake

instead of

big mistake

Other studies (Biskup, 1992; Bahns, 1993; Al-Zahrani, 1998; Howarth, 1998; Liu, 1999; Nesselhauf, 2004) found that non-native students' learning of a second language was frequently hampered by a lack of appropriate collocation knowledge. All these studies focused on problems with using collocations, both lexical and grammatical. Research by Saud (2018) titled "An Analysis of Collocation Errors Committed by EFL Students", found that students who studied English as a foreign language frequently had collocation problems, both lexical and grammatical. The most common errors were adjective-preposition errors, followed by verb-noun errors, while verb-preposition errors were the least common. In addition, Alsulayyi (2015) indicated that Saudi EFL students in the UK made fewer grammatical collocation errors than those learning English in KSA.

This categorization corresponded to Lewis (2000), who classified collocations into Lexical Collocations and Grammatical Collocations. Lewis defined Lexical Collocations as two or more content words (Noun, Verb, Adjective, and Adverb) that can be divided into 6 sub-categories, while Grammatical Collocation is the combination of content words and function words (mostly preposition) which can be divided into three patterns as shown in Figure 1. 


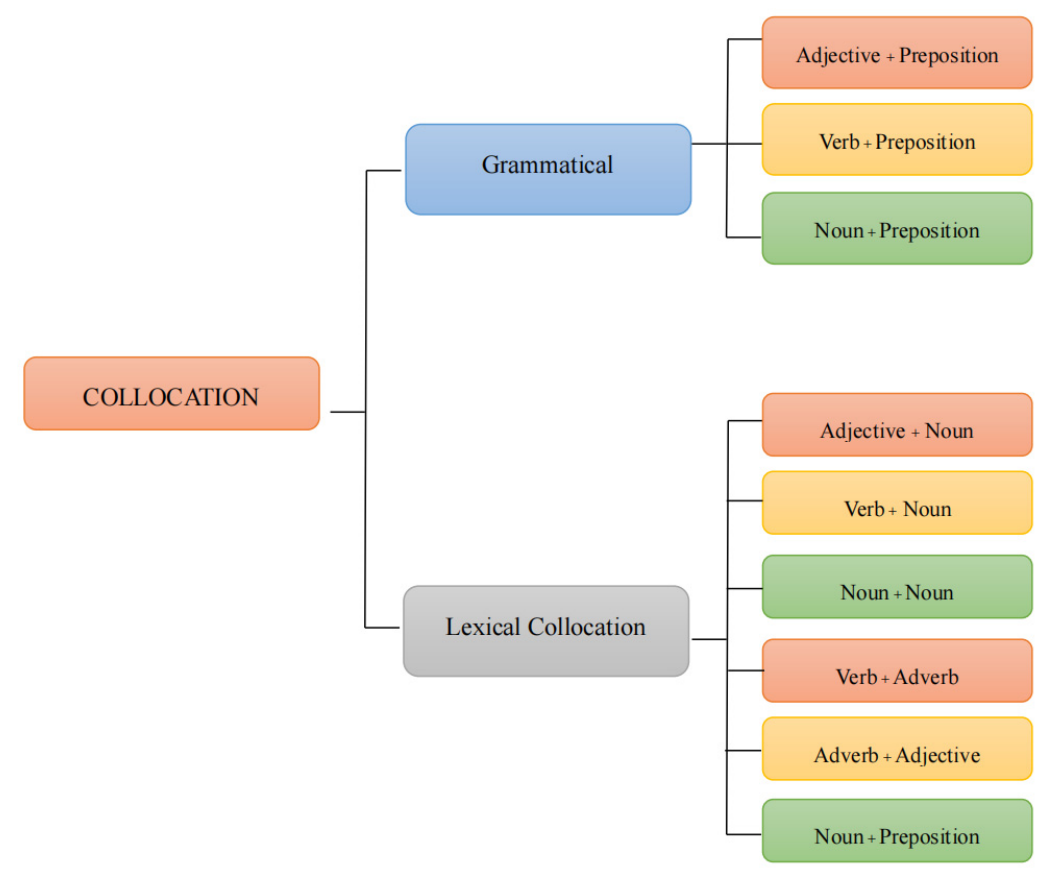

Figure 1. Collocation Classification

The meaning of Grammatical Collocation is the collocation between Noun, Verb or Adjective + Preposition, while Lexical Collocation is the collocation between Noun, Verb, or Adjective.

As a result, it's vital to look at the collocational faults of EFL/ESL student. The findings can be used to improve existing teaching and learning management models, to help language learners communicate more successfully, and to develop a natural fluent use of language akin to that of a native speaker. Because previous collocation research has primarily focused on grammatical or lexical collocation. This may provide insufficient information to encourage more research in the field and to motivate language educators to devote adequate time to it. The paper goes over some key definitions and categories, emphasizes the importance of collocations, describes the main research lines, and encourages motivation as well as a selection of classroom exercises to teach collocations. Furthermore, the current scenario has changed the teaching approach; today's technology has grown to the point where students can study independently at any time. The researcher can use the findings of this study to create an application or website that allows students to learn on their own at any time, not just in the classroom. It could also be a solution to difficulties that require a fresh approach in order to increase Thai students' overall skill levels. This study used Lewis's (2000) concept of classifying collocations to investigate collocation errors made by EFL students.

\section{Method}

This research used a qualitative approach by collecting data from students' collocation proficiency tests and analyzing their collocation errors.

\subsection{Research Objectives}

1) To study the collocation error level of BA English and Business English students at Northern Rajabhat University.

2) To study the relationship between first languages (L1) and second language (L2) transfer collocation errors in students' writing.

3) To compare the collocation errors between high-proficiency students, medium-proficiency students and low-proficiency students.

\subsection{Participant}

The research sample consisted of 285 Thai EFL students who were studying in the second-year of BA English and Business English programs at Northern Rajabhat University during the first semester of the academic year 2021. The sample was collected using Cluster Random Sampling and divided into High Proficiency, Medium Proficiency, and Low Proficiency according to their English scores on the Straightforward Quick Placement \& Diagnostic test. The Straightforward test had 50 questions, each worth one point. The score range considered to 
be high proficiency was 40-50. Those whose scores were 25-39 were assigned to the medium proficiency group and those whose scores were $0-24$ were assigned to the low proficiency group.

\subsection{Research Instruments}

The research instrument was the collocation proficiency test with 54 questions. The Index of Item-Objective Congruence (IOC) was used to find content validity. In this process, the test was checked by three English teaching experts. The test was divided into 2 sections: 1) a 36-question test with 4 multiple choices and 2) an 18-question Thai to English translation test. The Oxford Collocations Dictionary for Students of English (2008) was used to create the test items for both the multiple-choice and translation tests. The items were chosen from a list of 3,000 English words used to comprehend a Basic English text that EFL students should be familiar with. After the learners' completion of the test, the researcher analyzed the data by separating the categorization criteria into three error levels: high, medium, and low in order to evaluate the EFL students' collocation errors using Bloom's Cognitive Taxonomy (1986). The following is how the error levels were calculated using the mean score and percentage:
$80-100$ percent
Low level of collocation errors
$60-79$ percent
Medium level of collocation errors
$1-59$ percent
High level of collocation errors

\subsection{Data Collection and Data Analysis}

The research data was collected using the collocation proficiency test with the sample being Thai EFL students who were studying in their second year in the BA English and Business English programs at Northern Rajabhat University. Collocation errors were analyzed and compared between the 3 groups. The collocation proficiency test data were analyzed using mean, standard deviation, t-test (Dependent), and Friedman tests.

\section{Finding and Discussion}

\subsection{Finding 1: The Level of Collocation Errors of BA English and Business English Program Students at} Northern Rajabhat University

3.1.1 The Study Result for the Level of Collocation Errors of EFL Students was Compared to the Criteria of 80 Percent

In the study of collocation errors of EFL students, the researchers compared the criteria at 80 percent of the full score of 6 , so 80 percent of the full score was 4.80 marks. The research used a T-test with the test hypothesis as follows: $\mathrm{H} 0$ : the mean is equal to $80 \%$, and $\mathrm{H} 1$ : the mean is not equal to $80 \%$. The insignificance test result implied that the EFL students have a low level of collocation errors, whereas the significance test result implied a high level of collocation errors. The data analysis results are shown in Table 1.

Table 1. The collocation proficiency test results of EFL students compared to 80 percent criteria

\begin{tabular}{llllll}
\hline TYPE & n & Mean & SD & t-test & sig \\
\hline Grammatical Collocation & & & & & \\
Adj+pp & 285 & 2.69 & 1.50 & 23.77 & $.00^{*}$ \\
Verb+pp & 285 & 3.12 & 1.70 & 16.70 & $.00^{*}$ \\
Noun+pp & 285 & 2.55 & 1.61 & 23.64 & $.00^{*}$ \\
Average total & 285 & 2.73 & 1.62 & 34.96 & $.00^{*}$ \\
Lexical Collocation & & & & & \\
Adj+n & 285 & 3.37 & 1.27 & 18.92 & $.00^{*}$ \\
Verb+n & 285 & 2.92 & 1.29 & 24.65 & $.00^{*}$ \\
Noun+n & 285 & 2.19 & 1.24 & 35.65 & $.00^{*}$ \\
Verb+adv & 285 & 2.18 & 1.20 & 36.82 & $.00^{*}$ \\
Adv+adj & 285 & 1.80 & 1.00 & 50.51 & $.00^{*}$ \\
Noun+verb & 285 & 3.86 & 1.45 & 10.90 & $.00^{*}$ \\
Average total & 285 & 2.75 & 1.46 & 49.82 & $.00^{*}$ \\
Overall Average & & 2.99 & 1.56 & 40.86 & $.00^{*}$ \\
\hline
\end{tabular}

$*$ Sig $<.05$ 
As shown in Table 1, the hypothesis testing results with a t-test found the Sig. was lower than .05 , both overall and in each aspect. When considering the collocation errors test mean score, it was found to be between 1.80 and 3.86, which was below 4.80, and implied that the EFL students had a high level of collocation errors, statistically significant at .05. It can be said that both Grammatical Collocation and Lexical Collocation are difficult for EFL students.

3.1.2 The Study Results of Collocation Errors of EFL Students were Categorized as High, Medium, and Low Proficiency

The researchers set the categorization criteria into three error levels of high, medium, and low to determine the EFL students' collocation errors by applying Bloom's Cognitive Taxonomy (1986). The results of the data analysis is shown in Figure 2.

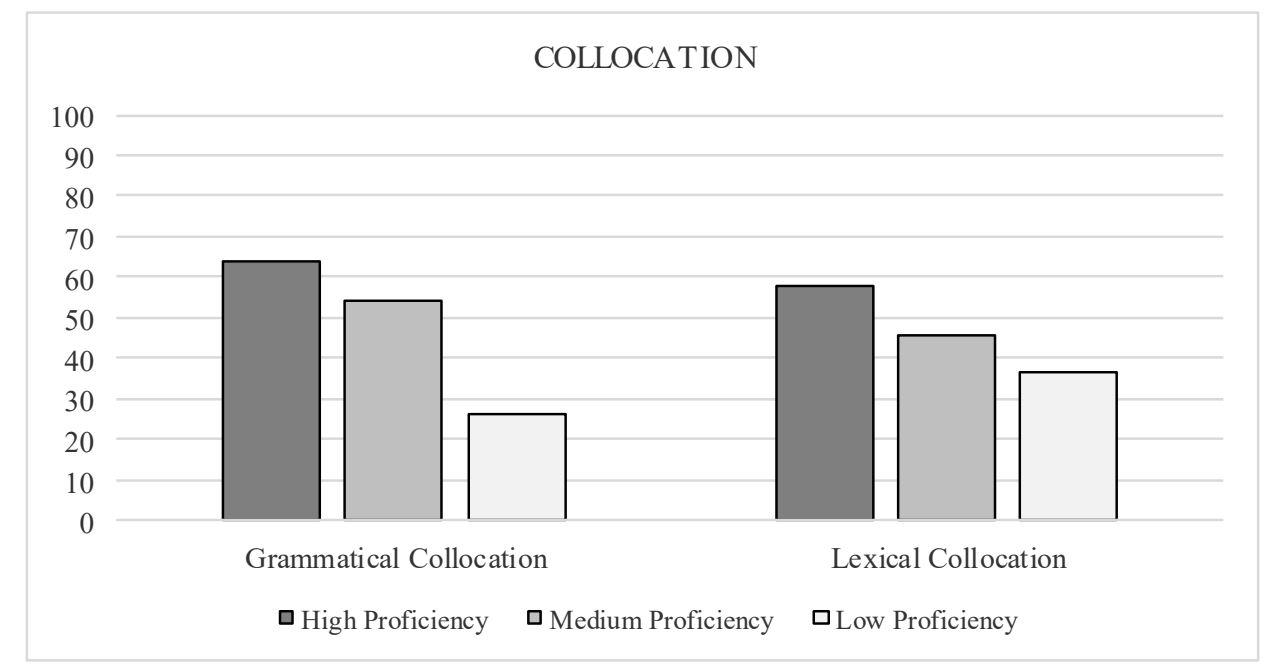

Figure 2. The proficiency of using collocations among EFL Students

As seen in Figure 2, the use of Grammatical Collocation by high proficiency EFL students had a mean score of 3.84 or 64 percent, which was at a medium error level. While medium proficiency EFL students had a mean score of 3.08 or 54 percent, low proficiency EFL students had a mean score of 1.58 or 26 percent. Both were at a high error level. High proficiency EFL students had a mean score of 3.47 or 58 percent for Lexical Collocation, medium proficiency EFL students had a mean score of 2.73 or 45.50 percent, and low proficiency EFL students had a mean score of 2.19 or 36.50 percent, with all three groups of EFL students having high error levels.

It is obvious from the above results that students have a high level of collocation errors. As a result, collocation can be considered a learning barrier for EFL students. Since it's possible that their collocation problems are due to a lack of basic collocation comprehension. Teachers had not previously taught them how to use collocations. When constructing lexical collocation, which is a mixture of two lexical terms, poor collocation knowledge could cause problems. Although several English terms may have the same meaning, they are employed in various contexts. As a result, Thai EFL writers created a collocation by combining terms that native speakers do not frequently use (Suthathip Thongvitit and Narathip Thumawongsa, 2017) Similarly, Manfu Duan (2012) concluded that the teaching of collocation in teaching practice has received insufficient attention. According to Varaporn (2013), despite the fact that students' collocation errors are regularly noted, Thai teachers have a limited understanding of the importance of collocations, and little study has been conducted on the subject. Furthermore, Dokchandra (2019) stated that during a conversation with the author, several of the students in this study indicated that they were not taught about collocations in high school, and that teachers in other classes at the university did not highlight the importance of collocations. Despite the fact that collocation is not a new concept in language education, it appears to be underused. In general, while teaching a second language, teachers separate grammar from vocabulary, simply focusing on the meaning of word. This method of instruction ignores a crucial feature of language: the use of a phrase or group of words, which leads to both Grammatical and Lexical Collocation. Collocations are relatively new to ESL learners and teachers in Pakistan, according to Anwar and Khan (2012), and are not included in mainstream English language education curricula. The majority of classrooms are organized on grammar and vocabulary, with a focus on the meanings of individual words. Furthermore, El-Dakhs (2015) stated that Pakistani ESL learners have difficulty using English appropriately due to a lack of attention on collocation in teaching and learning. 
Teaching each word separately will not assist EFL students in using vocabulary in the correct context. Although nowadays students can use modern technology to facilitate their education, they still need to be aware of the necessity of collocation so that they can use English more fluently, naturally, and similar to native speakers. The students should not learn only the correct usage of collocation, but also learn the usage errors. If teachers can point out collocation errors and mistakes, students could achieve higher levels of comprehension and accuracy. As such, teachers should encourage students to use more collocations in classrooms, and teachers also need to understand collocations so they can identify the causes of students' collocational errors and help students understand and use them correctly.

\subsection{Finding 2: The Relationship Between First Language (L1) and Second Language (L2) Transfer Collocation Errors in Students' Writing}

In this study, the relationship between first language (L1) and second language (L2) transfer collocation errors in students' writing was examined. The researchers analyzed the results from an 18-question translation test to study the collocation errors caused by native language transfer. The most significant approach students appeared to rely on was their native language. Synonymy was also utilized in their writing, which will be studied in detail further below.

\subsubsection{Native Language Transfer}

Most Thai EFL students rely on their first language (L1) by transferring and changing Thai into English. However, some English collocations have collocational mismatches with Thai language and mistakes can occur in both Grammatical and Lexical Collocation. The first error related to L1 influence is Preposition, which is categorized as Grammatical Collocation. The research found that Thai EFL students frequently omit an obligatory English preposition after a verb, which may be due to the literal translation of Thai verbs into English. For example:

(1) She wants to apply this position.

- Thai collocation: /sa - màk/ = "apply" and /tam - nècy/ = "position'

- Thai equivalents: apply this position

- Target English: collocation: apply for this position

From the above sentence, the error happened because the verb /sa - màk/ in Thai, which means "apply" in English, is a transitive verb, and the preposition after the verb is unnecessary. Hence, students who transfer L1 knowledge to their L2 collocation production might also omit prepositions in the target language, and the verb "apply" in English requires the prepositional phrase introduced by "for" at all times. This offers a reason why Thai EFL students make mistakes with Verb + Preposition collocation.

An inaccurate choice of preposition is another form of L1-transfer collocational problem associated with preposition use, as seen below:

(2) *They are really excited with traveling to Japan.

- Thai collocation: /tùumn - tên/ = 'excited', kâp/ = 'with' and káan - drrn - thaạ/ = "traveling"

- Thai equivalents: *excited with

- Target English: collocation: excited with traveling

The adjective + preposition collocation is one of the problematic collocation combinations commonly found in Thai EFL students, as well as Verb + Preposition collocation. The error in (2) is probably influenced by L1 transferring with the word /tùum - tên/ "Excited", Thai speakers always combine it with the preposition /kâp/ that can translate into English as "with", while the correct preposition for the word "Excited" is "about". This research found that all 3 groups of Thai EFL students, high, medium, and low proficiency, had the same error with "Excited". Instead of "excited about", Thai EFL students used "excited with", and the error number of High proficiency EFL students was $14 \%$, Medium proficiency EFL students was $21 \%$, and Low proficiency EFL students was $18 \%$ respectively.

Besides the errors mentioned above, the research also found that there were also Noun + Preposition collocation.

(3) * Mark is an expert side computer game.

- Thai collocation: /chîaw - cháan/ = "expert" and /dân/ = "side"

- Thai equivalents: *expert side computer games

- Target English: collocation: expert on computer games 
The statement is created using Thai structure, as shown in the sample above. In Thai, the word /chîaw - cháan/ which means "expert" in English, commonly co - occurs with /dân/. Whereas the word /dân/ means "side" in English, the appropriate preposition for "expert" is "on". This is one of the error examples caused by mother tongue interference for EFL students. This research found that all three groups of Thai EFL students (high, medium, and low proficiency) shared the same error using "expert side" instead of "expert on", and the number are high proficiency students was $5 \%$, medium proficiency students was $12 \%$ and low proficiency students was $8 \%$ respectively.

Another clear example of L1 interference was the misuse of Verb + Noun, Adverb + Adjective, and Noun + Verb Lexical Collocations found in EFL students' essays.

(4) * Can you book at/ place for me?

- Thai collocation: /coon/ = "book" and /thî:/ = "at / place"

- Thai equivalents: *book at / book place

- Target English: collocation: save a seat

(5) * My cat cries / sings all day.

- Thai collocation: /róoy/ = "cry / sing"

- Thai equivalents: *at cries / sings

- Target English: collocation: cat meows

In the examples above, Thai EFL students do not notice the target collocation. Some students made errors because they literally translated Thai into English. Moreover, some students may use dictionaries to search for the meaning of words, so they choose incorrect words when translating. Students may make collocational errors while producing English collocations from Thai meaning since some English terms have comparable meanings in Thai. From example (4), it is possible that when students search a dictionary to find the meaning of /thî:/ and find the words "at, place, and land" in that order, they choose the first word or the most familiar word without considering the word's function. This concept was found in research by Quping Hou and Issra Pramoolsook (2012) where some students made errors because they literally translated Chinese to English, as well as using Chinese language rules. Although these expressions are intelligible in Chinese, they are not grammatically correct in English.

As in example (5), the students used the same method as found in example (4) by transferring from their mother tongue directly and not being concerned with the specific function of the word or whether it is used with human or animal. In Thai, /róoy/ can be used with both human and animal subjects, but in English "cry" can be used with the subject that is human only and there are different words to describe different animals, e.g. cat-meow, dog - bark, or lion - roar.

\subsubsection{Synonyms}

The synonymy strategy has been reported as a common learning strategy in several studies of L2 English collocation acquisition (Farghal \& Obiedat, 1995; Howarth, 1998; Phoocharoensil, 2011; Yumanee \& Phoocharoensil, 2013), and synonymy is one of the difficulties students regularly face in vocabulary learning (Laufer, 1990). Because students' knowledge of the target language is limited, this analogy method is frequently used. As a result, their language learning tactics, such as substituting a collocation word with its synonym without being aware of the nonequivalent collocation pair, are based on the open-choice principle (Phoocharoensil, 2011). Much prior research has found that EFL students tend to replace a word in a second language with a synonym from their first language, resulting in errors. Although synonyms are words that have similar meanings, there are no perfect synonyms between the two languages. However, students with limited English language proficiency always believe both words can be used interchangeably use this technique because they lack necessary skills (M. Farghal and H. Obiedat) and because they believe both words can be used interchangeably. For example, students use "authentically believe" instead of "truly believe". Although, "truly" and "authentically" are synonyms, but they are used in different syntactic patterns, particularly in English collocations.

In this study, synonyms are one of the errors that were found in EFL students' writing. By assuming a semantic resemblance of the words and employing one of the collocation pairings, these collocations were formed by students. For example: 
(6) * We deeply sleep

- Thai collocation: /àp/= 'sleep' and /luik/ = 'deeply'

- Thai equivalents: * deeply sleep

- Target English: collocation: sleep soundly /well/ properly

(7) *direct flight

- Thai collocation: /troy/= 'straight' and /thîaw-bin/= 'flight'

- Thai equivalents: *straight flight

- Target English: collocation: direct flight

In the case of (6), the source of error appears to be relevant to synonymy. That is, students use *deeply sleep rather than "sleep soundly/well/properly" because they believe the two words (deeply and soundly/well/properly) are interchangeable. Although the words soundly/well/properly and deeply are technically synonymous, they are employed in distinct ways, particularly in English collocations. Although the terms deeply and soundly are similar in some ways, only soundly can co - occur with the verb sleep in the Longman Dictionary of Contemporary English Online and Cambridge Dictionary Online, as validated by the Oxford collocations dictionary for English students (2003, p. 720).

Furthermore, (7) is an example of a mistake made by EFL students while utilizing synonyms in their writing. The students chose "straight" over "direct" because in Thai these 2 words mean /troy/ and when searching in the dictionary both words were found. As such, the students chose "straight", which is more familiar, disregarding that "direct" can co - occur with the noun "flight".

All EFL students' collocation errors happened due to a lack of collocation comprehension, L1 to L2 transferring, and the use of synonyms in writing. As mentioned in Phoocharoensil (2011), L1 to L2 transferring can occur with high-proficiency students and low proficiency students. Unexpectedly, the high proficiency students also highly rely on the native language than the low proficiency students. Masoud Hashemi et al. (2012) discovered that EFL students create collocational errors in their writing as a result of mother tongue interference, lack of collocational concept, and a lack of collocational understanding. These could be some of the reasons why EFL students regularly use inappropriate collocations in their writing, and because of differences between their mother tongue and English, they might make collocation errors.

\subsection{Finding 3: The Comparison of Collocation Errors Among High-Proficiency Students, Medium-Proficiency Students, and Low-Proficiency Students}

In the study of the collocation errors of high-proficiency students, medium - proficiency students, and low proficiency students, the researchers analyzed the data using the Friedman test to compare the patterns of collocational errors between the different groups of students. The results of the analyses of collocation realizations are shown in the following two tables, Table 1, and Table 2. Table 1 shows Grammatical Collocation usage of the three proficiency levels, whereas Table 2 shows Lexical Collocation usage of the three proficiency levels. The results of the data analysis are shown in the following table:

Table 2. Grammatical Collocation usage of the three proficiency levels

\begin{tabular}{llllll}
\hline \multicolumn{2}{l}{ High-proficiency } & \multicolumn{2}{l}{ Medium-proficiency } & \multicolumn{2}{l}{ Low-proficiency } \\
\hline Ranks & Mean Rank & Ranks & Mean Rank & Ranks & Mean Rank \\
verb + pp & 2.21 & verb + pp & 2.47 & adj + pp & 2.56 \\
noun+pp & 1.90 & noun+pp & 1.91 & verb+pp & 1.83 \\
adj + pp & 1.88 & adj + pp & 1.62 & noun+pp & 1.61 \\
Asymp.Sig $=0.00$ & Asymp.Sig $=0.00$ & Asymp.Sig $=0.00$
\end{tabular}

As shown in Table 2, high-proficiency students and medium - proficiency students shared the same pattern of Grammatical Collocation errors in Verb + Preposition, Noun + Preposition, and Adjective + Preposition. Low proficiency students had grammatical errors such as Adjective + Preposition, Verb + Preposition, and Noun + Preposition. Moreover, low-proficiency students had the highest skills in using Adjective + Preposition, whereas high-proficiency students and medium - proficiency students were lowest. 
Table 3. Lexical Collocation usage of the three proficiency levels

\begin{tabular}{llllll}
\hline \multicolumn{2}{l}{ High-proficiency } & \multicolumn{2}{l}{ Medium-proficiency } & \multicolumn{2}{l}{ Low-proficiency } \\
\hline Ranks & Mean Rank & Ranks & Mean Rank & Ranks & Mean Rank \\
noun+verb & 5.04 & noun+verb & 4.87 & noun+verb & 4.89 \\
verb $+\mathrm{n}$ & 4.17 & adj+n & 4.45 & adj+n & 4.39 \\
adj $+\mathrm{n}$ & 4.15 & verb+n & 3.96 & verb+n & 3.47 \\
verb $+\mathrm{adv}$ & 3.11 & $\mathrm{n}+\mathrm{n}$ & 2.84 & $\mathrm{n}+\mathrm{n}$ & 2.98 \\
$\mathrm{n}+\mathrm{n}$ & 2.61 & verb+adv & 2.65 & verb+adv & 2.67 \\
adv + adj & 1.92 & adv + adj & 2.23 & adv+adj & 2.60 \\
Asymp.Sig $=0.00$ & Asymp.Sig $=0.00$ & Asymp.Sig $=0.00$
\end{tabular}

Table 3 shows the Lexical Collocation usage for the three proficiency levels, and that the Mean Rank of Noun + Verb collocation was highest for all groups. The mean rank for medium and low - proficiency students was Noun + Verb, Adjective + Noun, Verb + Noun, Verb + Noun, Noun + Noun, Verb + Adverb, and Adverb + Adjective. In conclusion, medium-proficiency and low-proficiency students had the same pattern of collocation errors, or the collocation errors found among high-proficiency students and medium-proficiency students were related.

This research showed that the collocation proficiency of the student groups varied widely. Errors were found in both Lexical Collocation and Grammatical Collocation. Every group had the most errors with Adverb + Adjective Lexical Collocation. This finding was supported by Martynska's (2004) study, which found that students found Adverb + Adjective collocational violations to be the most difficult and troublesome. As for Grammatical Collocation, there were errors with Verb + Preposition and Noun + Preposition in the same direction in all student groups, and the Mean Rank of Verb + Preposition was higher than Noun + Preposition. It can be concluded that students at all levels can perform Verb + Preposition better than Noun + Preposition, while the high-proficiency and medium - proficiency students have the lowest skills with Adjective + Preposition. Similarly, Beaty Novita Sari and Ingatan Gulö (2019) found that out of 35 collocation errors, the most common types of errors are Adjective + Preposition, while low - proficiency students have higher skills with Adjective + Preposition compared to two other groups. Other researchers, such as Bahns (1993) and Liu (1999) said that Grammatical Collocations should be stressed in the classroom. The current study demonstrates that a greater emphasis on learning Lexical Collocations is required, as well as the use of tactics other than error corrective feedback. Collocations is required, as well as the use of tactics other than error corrective feedback.

To sum up, any type of collocation can create difficulties or confusion for EFL students because there is no clear guideline for collocation usage. To determine which collocations are truly acceptable by native speakers or to better understand English collocation, one must first become aware of collocations and then experience them both receptively and productively. Instead of teaching new words like bath, exam, and friends, teachers can introduce them in groups, like have a bath, pass an exam, and make friends. To be fluent in a second language, it is not enough to learn individual words and their meanings. It's critical to understand how words mix to form chunks. Students will not be able to achieve a native - like level of competency if their sensitivity to diverse word relationships is not great enough or if words are not learned in chunks (Martynska, 2004).

In addition, collocations also help to achieve more natural speaking and writing levels similar to native speakers. For EFL students who wish to work in translation or interpreting, learning to use collocations frequently will enable them to work more efficiently.

\section{Conclusion and Pedagogical Recommendation}

The results of this research show that all three groups of EFL students have errors in two types of collocations, which are caused by a negative transfer from their mother tongue, synonyms, and a lack of collocation comprehension leading to inappropriate use of collocations in their writing.

There are pedagogical suggestions for EFL/ESL teachers and students, including collocation awareness. EFL students should be systematically taught to be aware of and recognize collocations in use on a regular basis (Ghazali, 2015). In this regard, teachers have a significant role to play in educating students to notice collocations in actual English on a regular basis. Additional exercises and tasks for improving collocation recognition can be found in a variety of newspapers and other internet resources. 
Furthermore, EFL students should be aware of collocation because it will assist them in producing appropriate word combinations in order to make proper and well - defined compositions as well as enhance their vocabulary. Additionally, English teachers should emphasize collocational knowledge and structures involved in both Grammatical and Lexical Collocation rather than teaching particular words. For example, when teaching new phrases like focus (v), a mistake (n), or heavy (adj.), teachers can teach them in groups like "focus on", "make a mistake", and "heavy rain". Furthermore, teachers should encourage EFL students to use a collocation dictionary to improve their knowledge of collocations. The employment of a collocational dictionary, as Lewis (2000, p. 99) proposed, will facilitate students' collocational usage, and is required for some classroom tasks "with intermediate and more advanced students".

\section{Limitation}

The research's disadvantage is that the study's target group was limited to English major undergraduate students. As a result, the findings of this study do not apply to English collocation errors made by Thai students in other majors or at different levels of education, such as secondary school students, in order to compare if the errors occur differently.

\section{Further Studies}

According to the findings of this study, English major undergraduate students lacked Collocation understanding, which could apply to students in other majors as well. To compare the ability to use Collocation and the error, research on the use of both types of Collocation should be undertaken with students from other majors who are not English majors. As a result, teaching and learning strategies that improve English competence among undergraduate students in various majors are being developed in order to be more efficient (similar to those of native speakers).

Because English has become an international language, it is now compulsory of all students, not only EFL students. There are also opportunities to engage with foreigners using English, so if students can comprehend and speak effectively in English, they will benefit. Furthermore, with today's changing teaching styles, the findings of this study can be used as a foundation for future research in the development of an application, website, or e-learning that encourages Collocation learning for interested learners so that students can learn on their own at any time.

\section{References}

Al Ghazali, F. (2015). Reinforcing Students' Collocational Competence in EFL Classrooms. International Journal of Bilingual \& Multilingual Teachers of English, 3(2), 105-116. https://doi.org/10.12785/ijbmte/030205

Alsulayyi, M. (2015). The Use of Grammatical Collocations by Advanced Saudi EFL Learners in the UK and KSA. International Journal of English Linguistics, 5(1). https://doi.org/10.5539/ijel.v5n1p32

Altuwairesh, N. (2016). Teaching collocations in EFL classroom. Arab World English Journal (AWEJ), 7(4), 13-20. https://doi.org/10.24093/awej/vol7no4.2

Al-Zahrani, M. S. (1998). Knowledge of English lexical collocations among male Saudi college students majoring in English at a Saudi university (Unpublished doctoral dissertation). Indiana University of Pennsylvania, Pennsylvania.

Anwar, R. M. B., \& Khan, L. A. (2012). Collocations and second language use: Errors made by advanced learners in Pakistan. Arts, Social Sciences, 47.

Ashiba, A. (2017). The impact of verb-noun collocations in the paragraph writing of Palestinian EFL learners in Gaza Universities (Unpublished master's thesis). Faculty of Education, AL-Azhar University- Gaza, Palestine.

Bahns, J. (1993). Lexical collocations: a contrastive view. ELT Journal, 47(1), 56-63. https://doi.org/10.1093/elt/47.1.56

Benson, M., Benson, E., \& Ilson, R. (2009). The BBI Combinatory Dictionary of English. Philadelphia, John Benjamins. https://doi.org/10.1075/z.bbi

Biskup, D. (1992). L1 Influence on Learners' Renderings of English Collocations: A Polish/German Empirical Study. Vocabulary and Applied Linguistics, 85-93. https://doi.org/10.1007/978-1-349-12396-4_8

Bloom, B. S. (1968). Learning for mastery. Evaluation Comment, 1(2). Retrieved from https://www.eric.ed.gov/ERICWebPortal/contentdelivery/servlet/ERICServlet?accno=ED053419 
Boonyasaquan, S. (2005). An analysis of collocational violations in translation. MANUTSAT PARITAT: Journal of Humanities, 27(2), 79-91. Retrieved from https://ejournals.swu.ac.th/index.php/hm/article/view/618/618

Boonyasaquan, S. (2009). The lexical approach: An emphasis on collocations. MANUTSAT PARITAT: Journal of Humanities, 28(1), 98-108. Retrieved from https:/ejournals.swu.ac.th/index.php/hm/article/view/626/627

Brown, H. (2000). Principles of language learning and teaching (4th ed.). Englewood Cliffs: Prentice-Hal.

Bui, T. L. (2021). The Role of Collocations in the English Teaching and Learning. International Jourrnal of TESOL \& Education, 1(2), 99-109. Retrieved from https://eoi.citefactor.org/10.11250/ijte.01.02.006

Cao, D., \& Badger, R. (2021). Cross-linguistic influence on the use of L2 collocations: the case of Vietnamese learners. Applied Linguistics Review. https://doi.org/10.1515/applirev-2020-0035

Conzett, J. (2000). Integrating collocation into a reading and writing course. In M. Lewis (Ed.), Teaching collocation: Further developments in the lexical approach (pp. 70-87). Hove, UK: Language Teaching Publications.

Deuter, M. (2008). Oxford collocations dictionary for students of English. Oxford University Press.

Dokchandra, D. (2019). Thai EFL learners' collocational competence and their perceptions of collocational difficulty. Theory and Practice in Language Studies, 9(7), 776-784. https://doi.org/10.17507/tpls.0907.04

Duan, M. (2012). Collocation in English teaching and learning. Theory and Practice in Language Studies, 2(9), 1890-1894. https://doi.org/10.4304/tpls.2.9.1890-1894

El-Dakhs, D. A. S. (2015). Collocational competence in English language teaching: An overview. Arab World English Journal (AWEJ), 6(1), 68-82. https://doi.org/10.24093/awej/vol6no1.5

Ellis, R. (1994). The study of second language acquisition. Oxford, UK: Oxford University Press.

Farghal, M., \& Obiedat, H. (1995). Collocations: A neglected variable in EFL. IRAL - International Review of Applied Linguistics in Language Teaching, 33(4). https://doi.org/10.1515/iral.1995.33.4.315

Firth, J. R. (1968). Linguistics and Translation. In F. R. Palmer (Ed.), Selected Papers of J. R. Firth (pp. 1952-1959). London: Longman.

Halliday, M., \& Hasan, R. (1976). Cohesion in English. Longman.

Hashemi, M., Azizinezhad, M., \& Dravishi, S. (2012). The investigation of collocational errors in university students' writing majoring in English. Procedia - Social and Behavioral Sciences, 31, 555-558. https://doi.org/10.1016/j.sbspro.2011.12.102

Hill, J. (2000). Revising priorities: From grammatical failure to collocational success. In M. Lewis (Ed.), Teaching collocation: Further development in the lexical approach (pp. 47-69). Oxford: Oxford University Press.

Hill, J. (2001). Revising priorities: From grammatical failure to collocational success. In M. Lewis (Ed.), Teaching collocation: Further development in the lexical approach (pp. 47-69). Hove, Language Teaching.

Hill, J., Lewis, M., \& Lewis, M. (2001). Classroom strategies, activities and exercises. In M. Lewis (Ed.), Teaching collocation: Further development in the lexical approach (pp. 88-116). Hove, Language Teaching.

Howarth, P. (1998). The phraseology of learners' academic writing. In A. P. Cowie (Ed.), Phraseology: Theory, analysis, and applications (pp. 161-186). Oxford, England: Oxford University Press.

Huang, Li-Szu. (2011). Knowledge of English collocations: An analysis of Taiwanese EFL learners. Proceedings of the Texas Foreign Language Education Conference, 6(1).

Iamsirirak, E. (2017). Teaching vocabulary in English literature for Thai L2 students through productivity-based instruction. International (Humanities, Social Sciences and Arts), 10(5), 144-158.

Intaraprasit, N. (2013). Investigation of Collocations Occurrence in English Novels. 6th RMUTTO Research Conference (pp. 1110-1116). Chon Buri, Thailand: Rajamangala University of Technology Tawan-ok.

Jindapitak, N. (2014). English pronunciation teacher preference: Thai university English learners' views. 8th International Technology, Education and Development Conference (pp. 4982-4991). Valencia, Spain.

Kuo, C.-L. (2009). An analysis of the use of collocation by intermediate EFL college students in Taiwan. ARECLS, 6, 144-155. 
Laufer, B. (1990). Words you know: How they affect the words you learn. In J. Fisiak (Ed.), Further insights into contrastive linguistics (pp. 573-593). Amsterdam: John Benjamins. https://doi.org/10.1075/llsee.30.35lau

Lewis, M. (2001). Language in the lexical approach. In M. Lewis (Ed.), Teaching collocation: Further development in the lexical approach (pp. 126-154). Hove, Language Teaching.

Lewis, M. (2001). There is nothing as practical as a good theory. In M. Lewis (Ed.), Teaching collocation: Further development in the lexical approach (pp. 10-27). Hove, Language Teaching.

Lewis, Michael. (2000). Learning in the lexical approach. In M. Lewis (Ed.), Teaching collocation: Further developments in the lexical approach (pp. 155-185). Hove, UK: Language Teaching Publications.

Liu, C. P. (1999b). An analysis of collocation errors in EFL writing. The Proceedings of the English International Symposium on English Teaching (pp. 483-494). Taipei: Crane Publishing Ltd.

Martynska, M. (2004). Do English language learners know collocations? Investigationes Linguisticae, 11, 1. https://doi.org/10.14746/il.2004.11.4

McCarthy, M., \& O'Dell, F. (2005). English collocations in use. Cambridge: Cambridge University Press.

McIntosh, C. (2009). Oxford collocations dictionary for students of English. Oxford: Oxford University Press.

Nation, I. (2001). Learning vocabulary in another language. Cambridge: Cambridge University Press. https://doi.org/10.1017/CBO9781139524759

Nesselhauf, N. (2004). How learner corpus analysis can contribute to language teaching: A study of support verb constructions. Studies in Corpus Linguistics (pp. 109-124). https://doi.org/10.1075/scl.17.08nes

Odlin, T. (1989). Language transfer: Cross-linguistic influence in language learning. Cambridge, England: Cambridge University Press. https://doi.org/10.1017/CBO9781139524537

Palmer, H. (1938). A grammar of English words. Longmans, Green and Co.

Phoocharoensil, S. (2011). Collocational errors in EFL learners' interlanguage. Journal of Education and Practice, 2(3), 103-120.

Phoocharoensil, S. (2014). Exploring learners' developing L2 collocational competence. Theory and Practice in Language Studies, 4(12), 2533-2540. https://doi.org/10.4304/tpls.4.12.2533-2540

Puimom, S., Kerdthong, J., \& Nimsa-Ard, C. (2012). A Survey of the Use of Collocation in Thai College Students' Writing. Retrieved from https://research.rmutsb.ac.th

Qader, D. (2018). The role of teaching lexical collocation in raising EFL learners' speaking fluency. Journal of Literature, Languages and Linguistics, 46, 42-53.

Quping, H., \& Pramoolsook, I. (2012). Non-English major EFL learners' lexical collocation errors in a Chinese context. Suranaree Journal of Social Science, 6(1). Retrieved from https://so05.tci-thaijo.org/index.php/sjss/article/view/23028

Richards, J., Platt, J., \& Platt, H. (1993). Dictionary of language teaching and applied linguistics. Longman.

Sanguannam, S. (2017). A study on "Delexical Verb+Noun" collocation errors of Thai EFL intermediate and advanced learners. Journal of Liberal Arts, 17(2), 59-84. Retrieved from https://so03.tci-thaijo.org/index.php/liberalarts/article/download/107079/84727/

Sari, B., \& Gulö, I. (2019). Observing Grammatical Collocation in Students' Writings. TEKNOSASTIK, 17(2), 25. https://doi.org/10.33365/ts.v17i2.325

Saud, W. (2018). An Analysis of Collocation Errors Committed by EFL Learners. Retrieved from https://www.researchgate.net/publication/341165037_An_Analysis_of_Collocation_Errors_Committed_by _EFL_Learners

Shamsudin, S., Sadoughvanini, S., \& Zaid, Y. (2013). Iranian EFL learners' collocational errors in speaking skill. Procedia - Social and Behavioral Sciences, 70, 1295-1302. https://doi.org/10.1016/j.sbspro.2013.01.190

Tanihardjo, J. (2017). Indonesian EFL students' production of English lexical collocation in writing. Journal of English Language and Culture, 7(2), 64-72. https://doi.org/10.30813/jelc.v7i2.1025 
Thanalertkul, S. (2009). Study of strategies in translation of adjective-noun collocations: a case study of translated narratives from the books hope and courage and love and share. Bangkok: Thammasat University.

Thongvitit, S., \& Thumawongsa, N. (2017). A corpus-based study of English collocations found in the abstracts of research articles written by Thai EFL Writers. International Journal of Social Science and Humanity, 7(12), 751-755.

Varaporn, S. (2013). An analysis of lexical collocations and colligations in the turnabout series novels at Assumption University. The New English Teacher, 7(2), 50-61.

Vygotsky, L. (1986). Thought and language. Cambridge, Mass: MIT Press.

Wattanaphichet, W. (1999). English by Example. (Large ed. 2nd Printing). Bangkok: Thaiways Publication.

Wei, L., Chang, C., Yang, C., \& Hsu, S. (2021). Undertaking Online Collocation Dictionary to Enhance Textual Translation Ability: An Experimental Study of Mainland Chinese EFL Learners. Journal of China-ASEAN Studies (JCAS), 1(2).

Wilkins, D. (1972). Do reading and interactive vocabulary instruction make a difference? An empirical study. TESOL quarterly, 31(1), 121-140. https://doi.org/10.2307/3587978

Wongpunya, W., \& Meesri, C. (2019). Misuse of Collocations of Low-Proficiency Thai EFL Students. Retrieved from https://ethesisarchive.library.tu.ac.th/thesis/2017/TU_2017_5821040499_8868_6967.pdf

Woolard, G. (2001). Collocation encouraging learner independence. In M. Lewis (Ed.), Teaching collocation: Further development in the lexical approach (pp. 28-46). Hove: Language Teaching.

Yamashita, J., \& Jiang, N. (2010). L1 influence on the acquisition of L2 collocations: Japanese ESL users and EFL learners acquiring English collocations. TESOL Quarterly, 44(4), 647-668. https://doi.org/10.5054/tq.2010.235998

\section{Copyrights}

Copyright for this article is retained by the author(s), with first publication rights granted to the journal.

This is an open-access article distributed under the terms and conditions of the Creative Commons Attribution license (http://creativecommons.org/licenses/by/4.0/). 